\title{
10 Global production and circulation of dominant ideologies
}

\author{
Mexico from the default debt crisis \\ to the Brady Plan (1982-1989)
}

\author{
Johanna Gautier Morin
}

\section{Introduction}

Since the 1990s with the Argentinian collapse, the Russian fiasco, and the Greek scandal, the legitimacy of the International Monetary Fund (IMF) and the World Bank seems prejudiced in the eyes of world public opinion. Long subject to criticism from left-wing activists and "Third World" advocates during the 1980s-1990s, these organizations became the target of authorized voices (Williamson, 1998; The Economist, 2000; Stiglitz, 2002). The Latin American stagnation exacerbated this negative image in the 1980s (Easterly, 2000). It went wrong in 1982 when Mexico was on the verge of bankruptcy and declared a moratorium on its debt to negotiate an emergency rescue plan with the IMF, the U.S. Federal Reserve, the U.S. Treasury, and multiple international investment banks. This episode marked a turning point in the history of the IMF (McKinnon, 1993; Boughton, 2000), as well as in transnational banking business and regulation. For the following decade, the Fund repeatedly imposed structural adjustments that did not achieve the expected outcomes and inaugurated a ten-year external debt crisis that spread to Argentina, Brazil, Chile, Uruguay, and the Philippines (Heyde, 1987; Masson, 2007). Bradlow (2000) and Marangos (2004) accused the Fund of imposing a top-down view of economic policies, which set aside the social dimension of these reforms and neglected human rights issues. From Lindholm (1977) to Klein (2007), many authors and official reports have blamed the Fund for its ill-adapted experimental methods and considered the terms of conditionality of its loans to be responsible for the macroeconomic catastrophe (UNDP, 2003; SAPRIN, 2004). The resulting recession aggravated the "legitimation crisis" of these "money doctors" (Habermas, 1973; Drake, 1994; Woods, 2006: 84-103). Since then, the IMF itself has contributed to understanding the causes and culprits of the crisis by engaging in self-criticism (Rogoff, 2003; Sgard, 2005; Martinez-Vazquez et al., 2001; Dreher et al., 2015).

However, this vision has overshadowed the role and agency of the Mexican government in the negotiations leading to liberalization reforms and the crucial role played by the international investment banks and banking associations that cooperated as soon as the risk of default became an imminent threat. Indeed, 
inflows of foreign capital had increased in Mexico after the oil shocks (López Herrera et al., 2015). In this context, the Mexican crisis marked a turning point in the history of global financialization.

The massive bailout orchestrated by the IMF to avoid a systemic and global banking crisis was a success. A common language shared by institutions and individuals from distinct socio-political contexts emerged at the heart of the negotiations. The long process of circulation and institutionalization of the dominant "general inventory" of economic ideas favored the presence of economists in the Mexican government (Colander \& Coats, 1989). The renewal of political elites in a country where neoliberalism had a specific national development turned Mexico into a key actor in the game played by international organizations, foreign investment banks, and the U.S. Treasury, despite the revolutionary tradition of the single-party system (Babb, 2001; Romero Sotelo, 2016). ${ }^{1}$ This chapter aims at understanding how negotiations have been conducted in a context of financial dependence and proposes a renewed interpretation of international financial cooperation and the role of economists in the ideological convergence that went along with the circulation of capital flows.

The section 2 presents the data, methods, and theoretical framework adopted in this chapter. The section 3 explores the links between the renewal of the elites and the production of the dominant ideology in the 1980s. The section 4 exposes the terms of the crisis and analyzes it as a proxy to understand the structural mechanisms of Mexican economic policies. The section 5 examines the global convergence in economic rationale at the heart of the negotiations between the Mexican government, the IMF, the U.S. Treasury, and investment banks involved in the defaulted loans. The section 6 highlights the failures of the reforms and adjustment programs.

\section{Data and method}

We consider that the application of economic thoughts and doctrines in Latin America has shaped multilateral institutions and financial practices globally, contrary to the dominant view of the history of liberal imperialism, which saw the sub-continent as an under-integrated periphery (Rostow, 1960). Following the subaltern studies' approach (Appadurai, 1986), we examine how liberal thoughts and theories have been integrated into Mexican political culture to inform the circulation of economic beliefs and practices on a global scale (Hauswedell et al., 2019).

Theoretically, we investigate the programmatic work of Pierre Bourdieu and Luc Boltanski on the "production of the dominant ideology" (Boltanski \& Bourdieu, 1976). The literature has not yet fully exploited the theoretical potential of this text. It has never been translated and still seems confusing for many readers, since it adopted the form of its topic and commingled stereotypes, commonplaces, inconsistencies, and discrepancies. Imitating Flaubert's Dictionary of Received Ideas (Flaubert, 1881), the authors compiled a broad series of sources illustrating the dominant ideology shared by economic elites and the 
media, through published texts, public statements, filmed debates, bibliographies, graphs, figures, definitions, and images. Heir to a long tradition in the sociology of knowledge (Durkheim, 1912; Parsons, 1951) and perpetuating the legacy of Marx and Engels's critical analysis of the dominant ideology (Marx \& Engels, 1932), this unique work was embedded in French political life. However, we can carefully transpose this theoretical approach to the transnational network of investment bankers, financial experts, and government officials who helped resolve the Mexican default debt crisis.

In order to do so, we use quantitative and qualitative data from IMF confidential documents, staff reports, and secretariat's circulars (Washington); U.S. Treasury and Federal Reserve documents (Washington and New York); OECD economic surveys (Paris); Bank of International Settlements' documents (Basel); press articles from Mexico, the United States, the United Kingdom, and France; investment banks' private archives (Midland Bank, Société Générale, Crédit Lyonnais); decrees and declarations by the Mexican President and members of government; and correspondence between all the parties held in the U.K. National Archives in Kew. Paul A. Volcker's papers held at the Seeley G. Mudd Manuscript Library in Princeton, NJ, contributed to the understanding of the bailout negotiations. We also interviewed former IMF President Jacques de Larosière, who was supervising the negotiations, and exploited Larosière's and his successor Camdessus's memoirs (Camdessus, 1995; Larosière, 2016). This data allows us to evaluate the spillover effect of the Mexican episode on international governance and private capital distribution.

\section{Production of the dominant ideology: from political strategy to cultural change}

During the 1970s and 1980s, the transnational neoliberal shift has rooted international expertise in a social philosophy that transcended economic policies (Brint, 1996). The energy crisis, the financialization of the global economy, and the information technology revolution have disrupted the power game by providing opportunities for emerging fractions and challenged the position of old-established social groups. National elites were neither homogeneous nor static, and the dominant emerging economic ideologies served the interests of a "nebula" of dominant groups, sharing converging interests despite the diversity of their social and cultural origins (Khan, 2012). ${ }^{2}$

Bourdieu and Boltanski showed how rhetoric and symbolic discourses supported similar transformations through an "optimistic evolutionism" and popularized a new classification system. They referred to this evolution as "converted conservatism" aimed at excluding both the conservative rear-guard and the progressive vanguard doomed to remain confined to the margins. Political and economic advisers, business leaders, mainstream media, and institutional experts promoted this "converted conservatism" as inevitable. This rhetoric undermined any political culture that would contradict it and embraced the theory of historical evolutionism by positioning the elite beyond political conflicts. The ideology of the death of ideologies imposed the idea of the finiteness 
of all political options, confirmed by the "lessons of history," which showed the shortcomings of past political regimes. In that respect, the famous Mexican artist Cantinflas mocked President Echeverría Alvarez: "We are neither of the left, nor of the right, but entirely the opposite" (Calomiris \& Haber, 2015: 366). The "converted conservatism" imposed a new vision and division of social values based on the opposition of two polarized registries:

Table 10.1 The affirmation of neoliberal values and new socio-cultural perspectives ${ }^{1}$

\begin{tabular}{ll}
\hline Old-fashioned conservatism and utopianism & Optimistic evolutionism \\
Past & Future \\
Tradition & Modernity \\
Archaism & Innovation \\
Inertia & Flexibility \\
Trade unionism & Entrepreneurship \\
Fixity & Pragmatism \\
Socialism & Technology \\
Fascism & Leadership \\
Political ideology & Science \\
Interventionism & Freedom \\
\hline
\end{tabular}

Note: ${ }^{1}$ This table synthesizes the keywords' polarizing discourses, as Bourdieu and Boltanski identified them in a scattered way throughout their analysis (Boltanski \& Bourdieu, 1976: 45-65).

The "optimistic evolutionism" was authorized and reinforced by the intellectual and scientific support of institutions "at the intersection of the academic field and the field of power" (Boltanski \& Bourdieu, 1976: 67). ${ }^{3}$ In this regard, professional economists were particularly exposed to this ambiguity between the fields, at the crossroads of academia, political expertise, consulting, business and media (Abbott, 1988; Maesse, 2015; Schmidt-Wellenburg \& Lebaron, 2018). Their growing importance inspired Markoff and Montecinos to talk about the "ubiquitous rise of economists" in all sectors, even beyond their initial training (Markoff \& Montecinos, 1993).

The redefinition of social positions was not limited to the elite of developed and democratic countries, contrary to the impression most Western literature might give. In some "developing" countries, according to the tripartition of the time, non-democratic political regimes and planned economies experienced the same social changes during the 1980s (San Miguel, 2004; Kothari, 2005). Rising fractions influenced by monetarist and public choice theories aimed their criticisms at the Keynesian interventionism of former regimes (Centeno \& Silva, 1998; Heredia, 2018). ${ }^{4}$ Among the groups jockeying for power in the Mexican regime, the supporters of this new doxa used their expertise as leverage to influence decision-makers and the public (Fourcade, 2009).

The Mexican crisis revealed the ideological struggles between experts within the single party. Economists inspired by developmentalism and dependency theory, and trained at Cambridge University, ${ }^{5}$ fought against the growing 
influence of orthodox economists educated at Yale, such as Jesús Silva Herzog Flores and Miguel Mancera, who finally came to power when President Miguel de la Madrid was elected in 1982 (Babb, 2001: 171-198). Elite groups thus opposed each other within an institutional frame that circumscribed the field of power between those governing the state and those representing private power. The 1980s witnessed the rise, within the government, of economic experts who would have remained outsiders a few decades earlier (Dezalay \& Garth, 2002).

The transnational dimension of their trajectory reinforced their position (Seabrooke \& Henriksen, 2017). The renewal of the political elite corresponded to the liberalization of the state-controlled economy initiated to cope with the external pressure of international competition and the internal social and economic crisis (Rodríguez \& Ward, 1994). Their legitimacy was anchored in their proclaimed scientific neutrality (Fourcade, 2006). In that sense, Mexico was not an isolated case. ${ }^{6}$ There was a structural function in the expansion of the dominant ideology. The discourse of power is not strictly meant to convince:

Its primary function is to direct action or to maintain the cohesion among executives by reinforcing, through ritual reassertion, the group's belief in the necessity and the legitimacy of his action. Converts preaching converts, those believers educated in the same dogma and endowed with the same thinking and action patterns, the same ethical and political dispositions, can forgo the proof, the wholeness and the logical control, agreeing only to explain the few elements about which their action is criticized or rejected. Their disjoint discourse occults the essential points, which are exactly everything that goes without saying, everything that is self-evident as long as it is tacitly understood between the self, anything that cannot be revealed without betraying the official intention of the discourse.

(Boltanski \& Bourdieu, 1976: 6)

The Mexican crisis presented an excellent opportunity for industrialized countries to reinvent their hegemony "by transitioning from the post-war 'embedded liberal' world order to the Reagan-Thatcher model of neoliberalism and global capitalism." Multilateral institutions transformed "their mandates to accommodate these ideological changes" (Chorev \& Babb, 2009: 461). The circulation of ideas unfolded in a multidimensional configuration. In a regime born of a revolution and led by an authoritarian ruling elite (Garrido, 2005; Langston, 2017), the logic of self-preservation of the dominant group compelled the Mexican apparatchiki to appoint a new political staff with a profile consistent with the standards of multilateral institutions. The evolution of the standards of governance in the 1980s-1990s led to the emergence of the infamous "Washington consensus." The end of the Bretton Woods system in 1971-73 left its institutions in desperate need of defining a new legitimate raison d'être (George, 1992; Chorev \& Babb, 2009). They seized the fight against inflation and over-indebtedness as a new battle horse (Wolf, 1965; Bradlow, 2000). 
Contrary to the experiences of the Chilean Chicago Boys under the Pinochet regime (Silva, 2009; Gautier Morin \& Rossier, 2021). Mexico's bailout plans of the 1980 s were systematically mediated by the international financial community and justified by developmentalist rhetoric and free-market experiments (Gunder Frank, 1984; Jorge \& Salazar-Carrillo, 1988; Woods, 2006). Indeed, according to the IMF's original articles, its responsibility to "promote" liberalization was limited to "current account transaction (i.e., goods and services) but not capital account (i.e., debt, portfolio equity and direct and real estate investment)" (Moschella, 2009: 858). Theoretically, member countries had the right to control capital movements until the 1995 amendment of IMF statutes, which gave the Fund full authority over transnational capital flows. The case of Mexico shows that such a modification of the institutional design was already embedded in the 1980s programs (Goldman, 1982).

\section{The crisis: a proxy to unveil information mechanisms}

In February 1982, the constant decline in Mexican international reserves compelled the government to devaluate the peso. ${ }^{7}$ From 1954 to 1976, Mexico had a fixed exchange rate regime, and its external debt was denominated in U.S. dollars. In 1980-81, the U.S. Federal Reserve raised its interest rates. ${ }^{8}$ As a result, Mexican debt increased sharply, while devaluation did not seem to stop the outflow of international reserves. The problem was not new to the government: since independence, Mexico had to deal with an external debt that made the country structurally vulnerable (Marichal, 1989; Costeloe, 2003). Similarly, in a remarkable transnational comparative study on the stability of banking systems, Charles Calomiris and Stephen Haber demonstrated how banking crises and credit scarcity were embedded in the political history of Mexico, where authoritarian political leaders, bank insiders, and minority shareholders formed coalitions of interest groups that determined access and distribution of capital. The expropriations perpetrated by the Institutional Revolutionary Party (PRI) worried most bankers who rarely engaged in investments (Calomiris \& Haber, 2015: 331-389).

Between 1824 and 2001, Mexico spent more than 45\% of the time in a state of default or restructuring (Oosterlinck, 2013: 700). After the first oil crisis, the country faced drastic currency devaluations. The oil manna allowed an unprecedented rise in world oil prices until 1979-80 and urged Mexico to invest heavily to meet international demand. The country became the sixthlargest producer in the world in 1980. The government accumulated external debts with international private banks to make such investments, and the IMF acted as a guarantor on behalf of Mexico, which gave the organization authority over the country's economic policies (Salas-Porras, 2014). However, when international oil prices fell abidingly, Mexico faced the worst liquidity crisis since the revolution. Severe devaluations were not sufficient to solve the problem (Gracida, 2007; Ángel Mobarak, 2010; Bruner \& Simms, 1987).

On August 12, 1982, Jesús Silva Herzog, Mexican Secretary of Finance and Public Credit, informed U.S. Federal Reserve Chairman Paul Volcker, U.S. Treasury Secretary Donald Regan, and IMF Managing Director Jacques de 
Larosière "that Mexico would be unable to meet its August 16 obligation to service an $\$ 80$ billion debt" (Federal Deposit Insurance Corporation, 1997: 192). According to American journalist Joseph Kraft, Herzog landed in Washington on August 13 to negotiate a moratorium on commercial bank debt. "In retrospect, after similar moves by many other countries, Silva Herzog's action hardly seems singular. At the time, in fact, it was a bombshell that shook an entire universe" (Kraft, 1984: 2-4).

What was fundamentally new, according to José Ángel Gurría, current secretary-general of the OECD and former director of the Public Credit Department of Mexico under Herzog, was that they did not

crawl to the international financial community as debtors seeking relief through some minor adjustment that could be made backstage. We walked in through the front door. We said we had a major problem with a capital P. We did not say the problem was a particular debt. We said the problem was the whole international financial structure. We said it was everybody's problem.

(quoted in Kraft, 1984: 3)

Indeed, the Mexican crisis posed a threat to the international banking system. Among the U.S. banks exposed to the Mexican default risk, the ratio of credit outstood to more than $30 \%$ of their capital funds for 54 establishments and up to $48 \%$ for Bank of America, 73\% for Manufacturers Hanover, 81\% for the European American Bank, and 115\% for the Allied Bank International. ${ }^{9}$ David Knox, World Bank Vice President for Latin America, urged commercial banks to increase their lending and encourage the recovery of growth in the region, or, at least, to establish provisions for the potential losses since international creditors were so deeply involved in the Mexican debt. ${ }^{10}$ Creditor banks finally agreed, at a meeting held at the Federal Reserve Bank of New York on August 19-20, to extend the loan to Mexico to $\$ 1.5$ billion through the Bank of International Settlements (BIS). The U.S. government committed to lending $\$ 2$ billion. The IMF designed these "bridging" loans to gain time to develop its support program, which would reach $\$ 4$ billion over the next three years (BIS, 1984). This episode can thus be understood as the bailout of international banks, more than the rescue of Mexico.

\section{Global convergence in economic rationale}

When granted, the extension of the loan guaranteed by the IMF and the BIS was conditional on a set of "arrangements," according to IMF terminology (Eckaus, 1986; Khan \& Sharma, 2003; Babb \& Carruthers, 2008). The borrowing country ought to

adopt comprehensive programs worked out in close consultation with the Fund and calculated to restore satisfactory payments positions over a 
period of time. These arrangements are intended to provide assurance . . . of sufficient inflows of credit to permit orderly and gradual adjustment.

(IMF, 1983: 19)

Close cooperation was needed between international bodies, private financial institutions, and the national government to "attain the goals of sustainable debt-servicing and viable balance of payments positions" (IMF, 1983: 79).

The press referred to the Mexican tragedy as a deus ex machina, but the IMF adjustment program had been discussed for two years before the liquidity crisis hit the country. According to the IMF staff report for the 1982 consultation with Mexico, the Fund had been discussing with representatives of the Mexican government since November 1981 (IMF, 1982c). However, coordination failed at finding a solution. On September 1, 1982, the Mexican government nationalized the private banking system, imposed comprehensive exchange controls, and suspended all private sector debt payments and most public sector principal debt payments. The Bank of Mexico devalued the peso several times before the end of the year. Inflation rates reached 100\% in December and brought the country into a severe recession. Per capita GDP declined by $11 \%$ over the next five years. During the same period, wages fell by about $30 \%$, unemployment increased, and investment and consumption contractions slowed down economic growth (Buffie \& Krause, 1989: 153-154).

The IMF and the Mexican government finally reached an agreement after the election of President Miguel de la Madrid in 1982. Former negotiators Jésus Silva Herzog became Secretary of Finance and Public Credit, Miguel Mancera Aguayo, Director General of the Bank of Mexico, and Héctor Hernández Cervantes, Secretary of Commerce. IMF staff representatives began working with Ariel Buira, Executive Director for Mexico. These men represented a new guarantee for the IMF, and the organization warmly welcomed their appointments. De la Madrid had voiced support for the stabilization program during his campaign, which was considered a "break in tradition" that made the Fund staff optimistic about future outcomes (Maroni, 1982). Relationships between the IMF and Mexican officials had been tense until then. The Fund reproached the Mexican to keep the organization "in the dark": the Mexicans declined to respond to the questionnaire the IMF had sent them and indicated that they did not want another visit from a Fund team (Truman, 1982). After the elections, it was thus in the Mexican government's interest to send "a team of English-fluent, foreign-trained technocrats whose close personal connections within international financial circles were an important asset" to negotiate the fate of the country with international banks, the IMF, and the U.S. government (Babb, 2001: 177).

Changes in political and administrative staff led to a shift in public policy towards development and liberalization. Nearly 25\% of the officials had studied in U.S. universities (Centeno, 1994: 117). Herzog, Aguayo, Cervantes, and Buira were all economists, graduating from Yale, Melbourne, and Manchester, respectively. These institutions were not the temple of neoliberalism, as were 
the University of Chicago and Columbia in the 1960s. ${ }^{11}$ Nevertheless, they were a place of design and standardization of economic expertise and political advice. Moreover, the political legitimacy of these new ministers and secretaries was based mainly on Western expertise. Mancera and Silva had studied with Federal Reserve Chairman Paul Volcker when he taught at Yale.

Beyond transnational circulation, a dissenting Mexican intellectual current, supported since the interwar period by a class of entrepreneurs and businessmen, had developed a strong lineage in the Austrian tradition of Hayek and Mises. The banker and intellectual Luis Montes de Oca, founder of the Banco Internacional and member of the Mises's Society for the Renewal of Liberalism, had introduced the Mont Pelerin Society to Mexico (Merchant, 2002; Denord, 2002; Mirowski \& Plehwe, 2009; Romero Sotelo, 2016). The more the single-party regime fell into crisis, the more influential this trend became in the Mexican upper class (Romero Sotelo et al., 2014). Although the new generation of policymakers was not associated with neoliberal think tanks, their training, and knowledge of English, facilitated their communication and understanding with international experts.

A new generation of "technopols" combined economic-oriented technical expertise taught abroad (mainly in the U.S.) with local political involvement. "Cosmopolitan ideas, understood, applied, and developed according to universalistic professional standards, became part of their selves" (Dominguez, 1997: 16). This set of intellectual tools was all the more critical for the success of negotiations with multilateral organizations and foreign administrations since IMF-supported programs were not preconceived. They were to be considered as a process that evolved along with a "multiplicity of potential pathways, driven by exogenous economic events, by policy actions of the national authorities" (Mussa \& Savastano, 1999: 84-85).

As a result, the more national staff shared the economic principles and worldviews of IMF staff, the more quickly the program could be implemented. Finally, the March agreement was adopted

at the behest of the new financial authorities, aimed at re-establishing a better balance between aggregate demand and supply as a means of curbing inflation and strengthening the balance of payment. The key element of this program [was] a reduction in the overall financial deficit of the public sector by the equivalent of $3 \%$ of GDP.

(IMF, 1982d: 3)

The program also encouraged "the depreciation of the peso and substantial increases in prices and tariffs of basic goods and services" (IMF, 1982d: 7).

\section{Failures and experimentations}

In December 1982, the IMF Extended Arrangement finally approved a three-year loan of $\$ 3.8$ billion to the Mexican government. The government 
committed to engaging free-market reforms regarding fiscal austerity, reduction of public expenditures, privatization of state-owned enterprises, lowering of trade barriers, deregulation of the national industry, and liberalization of foreign investment. The contract stipulated,

during the period of the extended arrangement, Mexico shall remain in close consultation with the Fund. These consultations may include correspondence and visits of officials of the Fund to Mexico or of representatives of Mexico to the Fund. Mexico shall provide the Fund, through reports at intervals or dates requested by the Fund, with such information as the Fund requests in connection with the progress of Mexico in achieving the objectives and policies set forth.

(IMF, 1982a)

In other words, Mexico remained under the IMF trusteeship for almost a decade. Other programs were adopted in 1986 and 1989, lasting until 1993, before the peso crisis in 1994-95 (Barkbu et al., 2012).

IMF's conditionalities imposed the restructuration of every aspect of the national economy. The semantic field used in the reports is enlightening: restructuring was associated with ideas of "satisfactory maturity," "progress," or "relevance" (IMF, 1982b: 12-13). During this decade of continuous restructuring, no IMF report assessed the efficiency and accuracy of the programs implemented. The report on the renegotiation of Mexico's External Debt of October 2, 1986, praised the attachment of the representatives of the governments of Mexico and the 14 creditor countries "to the successful implementation of the program, in particular, the revitalization of the productive sector of the economy, the liberalization of the trade system, and the improvement of public finances" (IMF, 1986).

The absence of evaluation and self-criticism revealed a lack of practical analysis. Michel Camdessus, managing director of the Fund from 1987 to 2000, was convinced that the problems Mexico was facing came from the government's inability or unwillingness to implement IMF requirements properly (Camdessus, 1995). He supported the idea shared by most orthodox economists that "government policy is the primary cause of economic depressions" (Bergoeing et al., 2002: 16). Camdessus welcomed the "outstanding results" of stabilization program during his first mandate: the deficit aggregate balance in public finances (more than 15\% of the GDP in 1987) moved into surplus during the 1990s, and inflation eased from 160\% to 8\% (Camdessus, 1995: 36). However, these parameters were not neutral since economic indicators did not take into account sustainable development, living standards, and development indices (Berthélemy \& Lensink, 1995).

The Mexican crisis marked a turning point in the history of sovereign debt. International creditors' financing and adjustment strategies of the 1970s showed its limits. The first solutions adopted focused on short-term "damagecontainment" policies (Griffith-Jones, 1989: 3). However, the Mexican crisis 
affected the majority of emerging markets and Latin American economies. In the 1980s, bank loans and foreign private capital declined sharply. Until the 1982 crisis, Mexico depended on governmental loans from commercial banks, multilateral financial institutions (IMF, World Bank, and Inter-American Development Bank), and foreign governments (mainly the United States) to finance its external deficit (Jorge \& Salazar-Carrillo, 1988). By the end of the decade, Mexico had radically changed the way it attracted foreign capital (see Table 10.2). The domestic economy was opening up to international capital flows, lowered its barriers for foreign investment, privatized state corporations, and extended stock exchange operations to private companies in the Bolsa de Valores de México, as well as in foreign exchanges, especially New York. ${ }^{12}$

In September 1983, the Organization of American States (OAS) held a conference in Caracas, Venezuela, on the problem of external debt in Latin American and Caribbean States. The idea emerged that countries should collaborate to exert collective pressure on the international financial community to establish different operating conditions: payment moratoriums would become habits rather than exceptions. Many observers have interpreted the Caracas consensus as an attempt to form a debtor cartel, and collectively suspend debt service payments, which would have threatened the entire global financial market (Anguiano Roch, 2000: 235). ${ }^{13}$ It became clear that the global financial community could no longer negotiate loan conditionality without debtor countries. Since international creditors were so involved in Latin American external debts, David Knox, World Bank Vice President for Latin America, evoked earlier, advised commercial banks to establish provisions for their potential losses. However, nothing came out of the Caracas meeting because each government preferred to negotiate individually with the IMF and private banks. ${ }^{14}$

In 1989, the new president, Carlos Salinas de Gortari, the "first economist to achieve the presidency, and the first with a Ph.D. (from Harvard)" (Ai Camp, 2017: 3-4), launched a new phase in the external debt restructuring, with the implementation of the Brady Plan (after Nicholas Brady, U.S. Treasury secretary). The debt relief plan implicitly recognized the evidence at the end of the

Table 10.2 The financing of the Brady Agreement (US\$ million)

\begin{tabular}{lrrrrrr}
\hline & Total & IMF & IBRD & Other & Own & Ratio $^{1}$ \\
\hline Costa Rica & 216 & 51 & 35 & 102 & 28 & 0.87 \\
Mexico & 7000 & 1697 & 2010 & 2050 & 1243 & 0.82 \\
Philippines & 670 & 170 & 150 & 107 & 243 & 0.64 \\
Uruguay & 463 & 34 & 65 & 38 & 326 & 0.30 \\
Venezuela & 2380 & 880 & 500 & 600 & 400 & 0.83 \\
\hline
\end{tabular}

Source: (OECD, 1992: 16; World Bank, 1990, 1991; IMF, 1991: 77). ${ }^{1}$ The ratio refers to the foreign contribution to the financing of the Brady deal. 
"lost decade" that many countries would not be able to repay their debts even if payment deadlines were further stretched (Sachs, 1989). The Plan called on commercial banks to step up lending to developing countries. This multilateral consensus induced a financial innovation with the creation of a secondary market that allowed debtors to trade their debt. ${ }^{15}$ The IMF and the World Bank played a key role in facilitating the lending and liquidity for Latin American governments. The area of application of their prescriptions soon exceeded Latin American or Western countries to reach Pakistan (Butt \& Jamal, 1988), India (Sau, 1983), Nigeria (Alawode, 1992), and Namibia (Morrell, 1983).

\section{Conclusion}

The implementation of the economic policy reforms resulting from the negotiations between the transnational networks of foreign banks, multilateral organizations, and sovereign governments must be understood at the heart of the production and circulation of the dominant ideologies that flourished in the 1970s-80s. The agency of the Mexican government, although limited by financial dependency, was not null, and the appointment of economists who graduated in U.S. and U.K. top universities as ministers and secretaries highlighted the country's degree of integration into financial globalization. Long considered a periphery of economic modernity, Mexico was, in fact, a central actor in the culture of the new capitalism. On the one hand, Mexican entrepreneurs and thinkers had contributed since the 1930s to the global development of neoliberal thinking. On the other hand, the IMF and commercial investment banks did not strictly design their arrangements during the debt crisis to save Mexico from bankruptcy but to avoid a systemic and global banking crisis.

The ad hoc structural adjustment plans and experimental reforms transformed Mexico and many other Latin American countries into the laboratory of economic policy experimentations that found their institutional legitimacy in the affirmation of the "Washington consensus" during the 1990s. Mexico contributed to the emergence of transnational technocratic expertise, both as a field for financial innovation and a proactive agent for economic integration. In that respect, the global tripartition of the 20th century between advanced, developing, and underdeveloped countries, according to the classic scheme of historical evolution, was the fruit of the dominant vision and division of the world whose legacy must be challenged and questioned by contemporary literature.

\section{Notes}

1 From the National Revolutionary Party (PNR) created in the aftermath of the revolution to the Institutional Revolutionary Party (PRI) in power until 2000, Mexico had no experience of a democratic regime all along the 20th century.

2 The term "nebula" captures the potential divergence between the economic interests of designated social groups but highlights how their beliefs and value system converged towards the same political agenda (Topalov, 1999). 
3 The identification of these institutions has been a work in progress worldwide for more than a decade, and the coverage of the international database is not yet complete (this includes data collection by the EurElite Project, the EASE-Project, the Swiss Elite Observatory, PELA-USAL in Latin America, etc.).

4 Economics as an academic field went through an existential crisis in the 1970s, especially in the United Kingdom and the United States. For the first time in economic history, with the global recession of 1973-75, inflation and unemployment rates exploded at the same time, while the Keynesian doxa had naturalized the idea that they were inversely proportional. Public sector borrowing increased and became an obsession in public debates. Since Keynesian theories proved incapable of addressing stagflation, the monetarist school and its quantity theory of money appeared as the only answer capable of solving the mystery of inflation (Jones, 2012; Mirowski \& Plehwe, 2009; Burgin, 2012).

5 Namely, socialist-oriented economists like Carlos Tello Macías, former Secretary of Budget and Planning, and José Andrés de Oteyza, Minister of Commerce and Industrial Development, in the cabinet of José López Portillo.

6 We can draw a parallel with Algeria, which has experienced a similar transition within its single-party system. This oil-producing country also had to borrow from the IMF and implemented its structural adjustment plan in the 1980s (Yefsah, 1992; Entelis, 2016).

7 Seeley G. Mudd Manuscript Library, Princeton, NJ, Paul Volcker's Papers (MC279), Box 24. Board of Governors of the Federal Reserve System. Incoming telegram from Mexico (02508) on February 3, 1982.

8 See Federal Funds Rate Historical Charts online: www.macrotrends.net/2015/ fed-funds-rate-historical-chart.

9 Paul Volcker's Papers (MC279), Box 24, Restricted-controlled documents.

10 Crédit Lyonnais Archives, M. A. David Knox to the Agence France Presse (AFP), February 25, 1986, SEF0305 4 F 0247 FRA/AFP-AP23, Int.-Eco.-Dette flt1, AFP 252116 FEV 86.

11 See the influence of Chicagoan theories in Latin America (Guillén Romo, 1994; Biglaiser, 2002).

12 Especially banks that had been nationalized in 1982, and the company Teléfonos de México.

13 Crédit Lyonnais Archives, Latin American Debt Folder (1985-1988), Box 91AH115.

14 M. A. David Knox to the Agence France Presse (AFP), February 25, 1986.

15 Banks could swap their loan portfolios against shares and better-quality obligations.

\section{References}

Abbott, A. (1988). The System of Professions: An Essay on the Division of Expert Labor. Chicago: The University of Chicago Press.

Ai Camp, R. (2017). Democratizing Mexican Politics, 1982-2012. Oxford Research Encyclopedia of Latin American History. Oxford: Oxford University Press, 1-23.

Alawode, A. A. (1992). Financial Deregulation and the Effectiveness of Bank Supervision in Nigeria. Savings and Development, 16(1), 101-113.

Ángel Mobarak, G. A. (del). (2010). La Paradoja del desarrollo financiero in Kuntz Ficker, S. (ed.). Historia económica general de Mexico de la colonia a nuestros días. Mexico: Colegio de Mexico, Secretaría de Economía, 635-666.

Anguiano Roch, E. (2000). México y la globalización financiera. Foro Internacional, 40(2), 213-254.

Appadurai, A. (1986). Theory in Anthropology: Center and Periphery. Comparative Studies in Society and History, 28(2), 356-361. 
Babb, S. (2001). Managing Mexico. Economists from Nationalism to Neoliberalism. Princeton, NJ: Princeton University Press.

Babb, S. \& Carruthers, B. (2008). Conditionality: Forms, Function, and History. Annual Review of Law and Social Science, 4, 13-29.

BIS. (1984). CH-000583-8A.BISA.7.18.12.DEA.16.43, BIS-World Bank data-sharing, 1984-04/1988-11-24: Statistics on external indebtedness: bank and trade-related non-bank external claims on individual borrowing countries and territories at endDecember 1982 and end-June 1983. OECD and BIS. April 1984.

Barkbu, B., Eichengreen, B., \& Mody, A. (2012). Financial crises and the multilateral response: What the historical record show. Journal of International Economics, INEC-02584, $1-14$.

Bergoeing, R., Kehoe, P. J., Kehoe, T. J., \& Soto, R. (2002). Policy-Driven Productivity in Chile and Mexico in the 1980s and 1990s. The American Economic Review, 92(2), $16-21$.

Berthélemy, J.-C., \& Lensink, R. (1995). The Impact of the Brady Plans on Debt Reduction and Short-Term Growth. Savings and Development, 19(2), 175-190.

Biglaiser, G. (2002). The Internationalization of Chicago's Economics. Economic Development and Cultural Change, 50(2), 269-286.

Boltanski, L., \& Bourdieu, P. (1976). La production de l'idéologie dominante. Actes de la recherche en sciences sociales, 2(2-3), 3-73.

Boughton, J. M. (2000). The IMF and the Silent Revolution: Global Finance and Development in the 1980s. Washington, DC: IMF.

Bradlow, D. D. (2000). Rapidly Changing Functions and Slowly Evolving Structures: The Troubling Case of the IMF. Proceedings of the Annual Meeting (American Society of International Law), 94, 152-159.

Brint, S. (1996). In an Age of Experts: The Changing Role of Professionals in Politics and Public Life. Princeton, NJ: Princeton University Press.

Bruner, R. F., \& Simms, J. M. Jr. (1987). The International Debt Crisis and Bank Security Returns in 1982. Journal of Money, Credit and Banking, 19(1), 46-55.

Buffie, E., \& Krause, A. S. (1989) Mexico 1985-86: From Stabilizing Development to the Debt Crisis. in Sachs, J. D. (ed.), Developing Country Debt and the World Economy. Chicago: University of Chicago Press, 141-168.

Burgin, A. (2012). The Great Persuasion. Reinventing Free Markets since the Depression. Cambridge, MA: Harvard University Press.

Butt, M. S., \& Jamal, H. (1988). A Monetarist Approach to Inflation for Pakistan. Pakistan Economic and Social Review, 26(2), 69-88.

Calomiris, C., \& Haber, S. (2015). Fragile by Design: The Political Origins of Banking Crises and Scarce Credit. Princeton, NJ: Princeton University Press.

Camdessus, M. (1995). La crise financière mexicaine, ses origines, la réponse du FMI et les enseignements à en tirer. Revue d'économie financière, 33, 35-45.

Centeno, M. A. (1994). Democracy within Reason: Technocratic Revolution in Mexico. Philadelphia: Pennsylvania State University Press.

Centeno, M. A., \& Silva, P. (Eds.). (1998). The Politics of Expertise in Latin America. New York: St Martins.

Chorev, N., \& Babb, S. (2009). The Crisis of Neoliberalism and the Future of International Institutions: A Comparison of the IMF and the WTO. Theory and Society, 38(5), 459-484.

Colander, D. C., \& Coats, A. W. (1989). The Spread of Economic Ideas. Cambridge: Cambridge University Press. 
Costeloe, M. P. (2003), Bonds and Bondholders, British Investors and Mexico's Foreign Debt, 1824-1888. Westport: Praeger.

Denord, F. (2002). Le prophète, le pèlerin et le missionnaire. La circulation internationale du néo-libéralisme et ses acteurs. Actes de la recherche en sciences sociales, 145, 9-20.

Dezalay, Y. \& Garth, B. G. (2002). The Internationalization of Palace Wars: Lawyers, economists and the contest to transform Latin American states. Chicago: The University of Chicago Press.

Dominguez, J. (Ed.). (1997). Technolopols: Freeing Politics and Markets in Latin America in the 1990s. University Park: Pennsylvania State University Press.

Drake, P. W. (1994). Money Doctors, Foreign Debts, and Economic Reforms in Latin America from the 1890s to the Present. Lanham: SR Books.

Dreher, A., Sturm, J.-E., \& Vreeland, J. R. (2015). Politics and IMF Conditionality. The Journal of Conflict Resolution, 59(1), 120-148.

Durkheim, E. (1912). Les formes élémentaires de la vie religieuse. Paris: PUF.

Easterly, W. (2000). The Lost Decades: Developing Countries Stagnation in Spite of Policy Reform, 1980-1998. Washington DC: Development Research Group. World Bank.

Eckaus, R. S. (1986). How the IMF Lives with Its Conditionality. Policy Sciences, 19(3), 237-253.

The Economist. (2000). The Washington Dissensus. The Economist. 23 June.

Entelis, J. P. (2016). Algeria: The Revolution Institutionalized. London: Routledge.

Federal Deposit Insurance Corporation (1997). History of the Eighties: Lessons for the Future: An Examination of the Banking Crises of the 1980s and early 1990s. Washington: FDIC Division of Research and Statistics.

Flaubert, G. (1881). Bouvard et Pécuchet, Paris: Alphonse Lemerre.

Fourcade, M. (2006). The construction of a global profession: the transnationalization of economics. American Journal of Sociology, 112(1), 145-194.

Fourcade, M. (2009). Economists and Societies: Discipline and Profession in the United States, Britain, and France, 1890s to 1990s. Princeton: Princeton University Press.

Gautier Morin, J. \& Rossier, T. (2021). The interaction of elite networks in the Pinochet regime's macro-economic policies. Global Networks, online first. DOI: 10.1111/ glob.12300.

Garrido, L. J. (2005). El Partido de la revolución institucionalizada (medio siglo de poder político en México). La formación del nuevo estado (1928-1945). Mexico: Siglo Ventiuno Editores.

George, S. (1992). Vieilles institutions et nouveaux désordres: la Banque mondiale et le Fonds monétaire international à la fin du XXe siècle. L'homme et la société, 105-106, 25-33.

Guillén Romo, H. (1994). El Neoliberalismo en América Latina. Investigación Económica, 54(209), 107-144.

Goldman, D. (1982). The Mexico Debt Crisis and the International Monetary Fund. EIR Economics, 9(33), 4-6.

Gracida, E. M. (2007). Reflexiones sobre el pensamiento económico en México, 19701986. Iberoamericana, 7(26), 67-87.

Griffith-Jones, S. (1989). The International Debt Problem: Prospects and Solutions in Singer, H. W., \& Sharma, S. (eds.). Economic Development and World Debt. New York: St. Martin's.

Gunder Frank, A. (1984). World Economic Crisis and Third World in the Mid-1980s. Economic and Political Weekly, 19(19), 799-804.

Habermas, J. (1973). Legitimationsprobleme im Spätkapitalismus. Frankfurt: Suhrkamp.

Hauswedell, T., Körner, A. \& Tiedau, U. (2019). Re-Mapping Center and Periphery. Asymmetrical Encounters in European and Global Contexts. London: UCL Press. 
Heredia, M. (2018). The International Division of Labor in Economists' Field: Academic Subordination in Exchange for Political Prerogatives in Argentina. Historical Social Research/Historische Sozialforschung, 43(3), 303-328.

Heyde, J. M. (1987). The Baker Plan Struggles for Results. Harvard International Review, 9(4), 36-38.

IMF (1982a). Mexico Extended Arrangement Agreed at Executive Board Meeting 82/168. December 23, 1982. EBS/82/208, Supplement 4.

IMF (1982b). Mexico Extended Arrangement agreed at Executive Board Meeting 82/168. Attachment II: Technical Memorandum of Understanding. December 23, 1982.

IMF (1982c). Mexico - Staff Report for the 1982 Article IV Consultation. SM/82/121. June 25, 1982.

IMF (1982d). Statement by Mr. Buira on Mexico. Executive Board Meeting 82/99. July 16, 1982.

IMF (1983). Annual Report of the Executive Board for the Financial Year Ended April 30, 1983. Washington, DC.

IMF (1986). Report on Renegotiation of Mexico's External Debt, prepared by the Western Hemisphere Department (WHD) and the Exchange and Trade Relations Department (ETR), October 2, 1986. EBS/86/225.

IMF (1991). International Capital Markets: Developments, Prospects, and Key Policy Issues. World Economic and Financial Surveys. Washington, DC: IMF Publications.

Jones, D. S. (2012). Masters of the Universe: Hayek, Friedman, and the Birth of Neoliberal Politics. Princeton, NJ: Princeton University Press.

Jorge, A., \& Salazar-Carrillo, J. (1988). Foreign Investment, Debt, and Economic Growth in Latin America. New York: Springer.

Khan, M. S., \& Sharma, S. (2003). IMF Conditionality and Country Ownership of Adjustment Programs. The World Bank Research Observer, 18(2), 227-248.

Khan, S. R. (2012). The Sociology of Elites. Annual Review of Sociology, 38, 361-377.

Klein, N. (2007). The Shock Doctrine: The Rise of Disaster Capitalism. New York: Metropolitan Books.

Kothari, U. (Ed.). (2005). A Radical History of Development Studies: Individuals, Institutions, and Ideologies. Chicago: University of Chicago Press.

Kraft, J. (1984). The Mexican Rescue. New York: The Group of Thirty.

Langston, J. (2017). Democratization and Authoritarian Party Survival: Mexico's PRI. New York: Oxford University Press.

Larosière (de), J. (2016). Cinquante ans de crises financières. Paris: Odile Jacob.

Lindholm, R. W. (1977). A Tested Program for Third World Economic Development. The American Journal of Economics and Sociology, 36(2), 165-169.

López Herrera, F., Santillán Salgado R. J., \& Cruz Ake S. (2015). Volatility Dependence Structure between the Mexican Stock Exchange and the World Capital Market. Investigación Económica, 74(293), 69-97.

Maesse, J. (2015). Economic Experts: A Discursive Political Economy of Economics. Journal of Multicultural Discourses, 10(3), 279-305.

Marangos, J. (2004). Was Shock Therapy Consistent With Democracy? Review of Social Economy, 62(2), 221-243.

Marichal, C. (1989). A Century of Debt Crises in Latin America: From Independence to the Great Depression, 1820-1930. Princeton, NJ: Princeton University Press.

Markoff, J., \& Montecinos, V. (1993). The Ubiquitous Rise of Economists. Journal of Public Policy, 13(1), 37-68. 
Maroni, Y. (1982). Mexico: Implementation of April 21 Stabilization Program, Restricted. Paul Volcker's Papers (MC279), Box 24, Folder Mexico 1982-1984, Seeley G. Mudd Manuscript Library, Princeton, NJ.

Martinez-Vazquez, J., Rioja, F., Skogstad, S., \& Valev, N. (2001). IMF Conditionality and Objections: The Russian Case. The American Journal of Economics and Sociology, 60(2), 501-517.

Marx, K., \& Engels, F. (1932). Die deutsche Ideologie [1846]. Moscow: Marx-Engels Institute.

Masson, P. R. (2007). The IMF: Victim of Its Own Success or Institutional Failure? International Journal, 62(4), 889-914.

McKinnon, R. I. (1993). The Rules of the Game: International Money in Historical Perspective. Journal of Economic Literature, 31(1), 1-44.

Merchant, L. A. (2002). Colapso y reforma. La integración del sistema bancario en el México revolucionario, 1913-1932. Mexico: Miguel Ángel Porrúa-Universidad Autónoma de Zacatecas.

Mirowski, P., \& Plehwe, D. (Eds.). (2009). The Road From Mont Pelerin: The Making of the Neoliberal Thought Collective. Cambridge, MA: Harvard University Press.

Morrell, J. (1983). The International Monetary Fund and Namibia. Africa Today, 30(1-2), $17-22$.

Moschella, M. (2009). When Ideas Fail to Influence Policy Outcomes: Orderly Liberalization and the International Monetary Fund. Review of International Political Economy, 16(5), 854-882.

Mussa, M., \& Savastano, M. (1999). The IMF Approach to Economic Stabilization. NBER Macroeconomics Annual, 14, 79-122.

OECD Development Center. (1992). An Assessment of the Brady Plan Agreements. Working Paper, 67, 1-46.

Oosterlinck, K. (2013). Sovereign debt default: Insights from history. Oxford Review of Economic Policy, 29(4), 697-714.

Parsons, T. (1951). The Social System. New York: The Free Press.

Rodríguez, V. E., \& Ward, P. M. (1994). Disentangling the PRI from the Government in Mexico. Mexican Studies/Estudios Mexicanos, 10(1), 163-186.

Rogoff, K. (2003). The IMF Strikes Back. Foreign Policy, 134, 38-46.

Romero Sotelo, M. E., Ludlow, L., \& Arroyo, J. P. (Eds.). (2014). El Legado intellectual de los economistas mexicanos. Mexico: UNAM,

Romero Sotelo, M. E. (2016). Los orígenes del neoliberalismo en México. La Escuela Austriaca. Mexico: Fondo de Cultura Económica/UNAM.

Rostow, W. W. (1960). The Stages of Economic Growth: A Non-Communist Manifesto. London: Cambridge University Press.

Sachs, J. (1989). Making the Brady Plan Work. Foreign Affairs, 68(3), 87-104.

Salas-Porras, A. (2014). Las élites neoliberales en México: ¿cómo se construye un campo de poder que transforma las prácticas sociales de las élites políticas? Revista Mexicana de Ciencias Políticas y Sociales, LIX(22), 279-312.

San Miguel, P. L. (2004). La representación del atraso: México en la historiografía estadounidense. Historia Mexicana, 53(3), 745-796.

SAPRIN. (2004). Structural Adjustment: The SAPRIN Report: The Policy Roots of Economic Crisis, Poverty and Inequality, London: Zed Books.

Sau, R. (1983). Structural Adjustment in the Indian Economy: IMF Model of ImportPushed Growth. Economic and Political Weekly, 18(19/21), 779-788.

Schmidt-Wellenburg, C., \& Lebaron, F. (2018). There is No Such Thing as 'the Economy': Economic Phenomena Analysed from a Field-Theoretical Perspective. Historical Social Research, 43(3), 7-38. 
Seabrooke, L. \& Henriksen, L. F. (Eds.) 2017. Professional Networks in Transnational Governance. Cambridge: Cambridge University Press.

Sgard, J. (2005). Le principal, l'agent et l'évaluateur: comment expliquer l'échec du FMI en Argentine? Critique internationale, 27, 31-41.

Silva, P. (2009). In the Name of Reason: Technocrats and Politics in Chile, Philadelphia: Penn State University Press.

Stiglitz, J. (2002). Globalization and Its Discontents. New York: W. W. Norton \& Co.

Topalov, C. (1999). Laboratoires du nouveau siècle. La nébuleuse réformatrice et ses réseaux en France (1880-1914). Paris: Editions de l’EHESS.

Truman, T. (1982). Restricted document addressed to Paul Volcker. Board of Governors of the Federal Reserve System. April 20, 1982. Seeley G. Mudd Manuscript Library, Princeton, NJ.

UNDP. (2003). Human Development Report 2003. New York: Oxford University Press.

Williamson, J. (1998). The Washington Consensus Revisited. In Emmerij, L. \& Nuniiez del Arco, J. (eds.). El desarrollo economico y social en los umbrales del siglo XXI. Washington, DC: IDB.

Wolf, C. Jr. (1965). The Political Effects of Economic Programs: some indications from Latin America. Economic Development and Cultural Change, 14(1), 1-20.

Woods, N. (2006). The Globalizers: The IMF, the World Bank, and Their Borrowers. Ithaca: Cornell University Press.

World Bank. (1990). World Debt Tables, 1990-91, Country Tables. Washington, DC: World Bank Publications.

World Bank. (1991). Financial Flows to Developing Countries. Quarterly Review. Paper \#21968. Washington, DC: The World Bank Debt and International Finance Division.

Yefsah, A. (1992). L'armée et le pouvoir en Algérie de 1962 à 1992. Revue des mondes musulmans et de la Méditerranée, 65, 77-95. 